\title{
DIETARY EXPOSURE OF EGYPTIAN CUSTOMERS TO PESTICIDES RESIDUES AND CONTAMINANTS IN SOME FOOD ITEMS
}

Salama, E. Y.; Mona A. Khorshed and Abir A. El-Gohary

Central Laboratory of Residue Analysis of Pesticides and Heavy Metals in Food Agriculture research center,

\begin{abstract}
These studies were estimated the Dietary Exposure of the Egyptian people to pesticide residues (325 pesticides), PCB's (14 congeners), heavy metals ( $\mathrm{Fe}, \mathrm{Cu}$, $\mathrm{Cd}, \mathrm{pb}, \mathrm{Cr}$ and $\mathrm{Zn}$ ), nitrates and aflatoxines (B1,B2,G1 and G2) contamination in food. The Dietary Intakes were based on the total Diet Studies approach have been studied in the year 2008 depending on Egyptian National Food Consumption Data issued by Ministry of Agriculture.

The items and composites were selected according to their popularity and high consumption representing all groups of food and origin.

The pattern of residues showed that no organochlorine pesticide residues or PCB's were detected in samples, Only Azoxystrubin, Chlorpyrifos, Chlorafenpyr,I-Cyhalothrin and Profenofos were detected in low concentrations and not exceeding their ADIs. All the detected heavy metal element concentrations were below their acceptable values. The mean concentration of total aflatoxin was below their ADIs. All the samples were contaminated with nitrates within the acceptable limits. Generally all detected samples were within the international limits and no exceeding were found.
\end{abstract}

\section{INTRODUCTION}

National authorities have the responsibilities and obligation to ensure that toxic chemicals, such as pesticides, heavy metals, environmental and naturally occurring toxins, are not present in food at levels that may adversely affect the health of consumers. Governments need to assess public health risks arising from the presence of toxic chemicals in food by estimating the actual dietary intake of contaminants for comparison with their corresponding toxicological reference intake, such as the acceptable daily intake (ADI) or provisional tolerable weekly intake (PTWI). GEMS/Food Total Diet Studies report (1999).

The total diet study provides the most accurate estimates of intakes of contaminants for a country as a whole. In addition total diet studies explicitly take into account the kitchen preparation of foods to assess the levels of contaminants in foods as consumed and national food consumption data. One of the advantages of total diet studies is that they produce information that is readily understandable for use by regulatory agencies, decisionmakers and the public GEMS/Food Total Diet Studies report (2002).

This study is aimed to collect the highly consumed and the most popular food from the local market, and prepared as consumed (eaten) by the Egyptian peoples passing through all kitchen processes and submitting them into residue analysis of pesticides, heavy metals, aflatoxines and nitrates to characterize and evaluate the hazard for measuring the exposure and risk evaluation for the Egyptian people depending on the Egyptian food consumption data \{Food Balance Sheet (2006)\} and local habits for preparing and cooking processing . 


\section{MATERIALS AND METHODS}

Sampling

Twenty five samples were collected from different local markets in Great Cairo during 2008-2009. Samples were selected according to their popularity, high consumption, representing animal and plant origin and eaten by most people of the different stratified social levels. Samples have been passed through standard operating procedures (SOP) for preparing the samples in the kitchen as consumed. All operations such as blending, chopping, mixing and storing of samples were potential sources of extraneous contamination. This type of post preparation contamination must be avoided by careful selection of contamination-free blending equipment and storage containers. All prepared food items were weighed and mixed with a large-scale cutting and blending utensils and large capacity equipment were used to ensure adequate bulk homogenous sample preparation. All kitchen vessels and tools used for food processes were stainless steel. The samples were subjected to the different methods of analysis and kept at $-20^{\circ} \mathrm{C}$ to avoid any degradation due the complexity of matrices. The food items and preparation method are illustrated in table (1).

Table (1): Food items and methods of preparation

\begin{tabular}{|l|l|}
\hline Food item or composite & Food preparation method \\
\hline Rice & a- Boiled \& b- Fried with corn oil and mixed \\
\hline Macaroni & a- Boiled \& b- Boiled with tomato paste \\
\hline Wheat (Belela) & Boiled \\
\hline Bread & Chopped and mixed \\
\hline Bakery product & Chopped and mixed \\
\hline Vegetable mixture soup & $\begin{array}{l}\text { Boiled green peas, green beans, carrot, potatoes, squash } \\
\text { and parsley }\end{array}$ \\
\hline Green Salad & $\begin{array}{l}\text { Mixture of washed vegetables of lettuce, carrot, tomato, } \\
\text { cucumber, water cress, radish, leek and parsley }\end{array}$ \\
\hline Potatoes & a-Boiled \& b- Cheeps \\
\hline Broad bean (Medames) & Boiled \& mixed \\
\hline Cowpea & Boiled \& mixed \\
\hline Dry bean(white) & Boiled \& mixed \\
\hline Lentils & a- with skin (black) and b- without skin (yellow) \\
\hline Milk & Mixed \\
\hline Cheese & a- skimmed and b- whole milk \\
\hline Chicken & Boiled \\
\hline Veal meal & Boiled \\
\hline Liver meat & Boiled \\
\hline Fish & Edible parts (without head, tail, bones etc.) \\
\hline Apple & Rinsed, core, chopped not peeled \\
\hline Orange & Rinsed and Peeled \\
\hline Grape & Rinsed \\
\hline Peanut & Mixed \\
\hline Water & Mixed \\
\hline & \\
\hline
\end{tabular}




\section{Preparation instructions:}

In order for foods to be prepared in a consistent and unambiguous manner some instructions were taken into consideration.

Chopping, Samples were put into the appropriate sized food processor and chopped until a homogeneous mixture is attained- usually 6-8 minutes depending on the moisture content of the sample.

Blending. Samples were put into appropriate sized blender (depending on the amount of the item being prepared) and blended until a homogeneous mixture is obtained-usually 2-4 minutes depending on moisture content of the sample.

Combining Units of the same sample were combined before chopping or blending.

Compositing. Involves through mixing / blending / chopping of equal weights of the indicated samples.

Selection of appropriate food preparation equipment is a vital component of the contamination control procedures:

Gloves a non-lubricated surgical-style gloves were worn whenever the food being prepared could come into contact with hands.

Utensils Stainless steel knives, wooden (good quality, smooth, crack free) or glass chopping boards, large stainless steel or Pyrex receptacle (jug or bowl) for mixing liquids.

Equipment domestic oven, blenders, glass with stainless steel blades, food processors, large stainless steel pots.

Analytical quality control and quality assurance procedures:

All analytical methods and instructions were carefully validated as a part of the laboratory quality assurance system and were audited and accredited to $17025(2005)$ by the Centre of Metrology and Accreditation Service (FINAS).

Trace analysis of a wide range of complex matrices is an exacting science. For the reason, it is essential to have quality control steps in place to ensure confidence in the methodology and robustness of the results including the following: Blanks, duplicates, certified reference materials (CRMs), spike recovery (Acceptable recoveries for trace analysis would generally be 70 $120 \%$ ) and coefficient of variation of less than $20 \%$, in-house control samples and blind duplication were done as well. EURACHEM 2003

\section{Chemicals and reagents:}

Acetonitrile $(\mathrm{MeCN})$, methanol $(\mathrm{MeOH})$, de-ionized water for LC-MSMS mobile phase and as a reagent blank, organic solvents were sufficient quality for pesticide residue analysis, magnesium sulphate $\left(\mathrm{MgSO}_{4}\right)$ and sodium chloride $(\mathrm{NaCl})$, Reagent grade anhydrous $\mathrm{MgSO}_{4}$ in powder form and ACS-grade $\mathrm{NaCl}$ were obtained from Merck (Darmstadt, Germany) $\mathrm{MgSO}_{4}$ was baked for $5 \mathrm{hr}$ at $500^{\circ} \mathrm{C}$ in muffle furnace to remove phthalates. Organic acids, glacial acetic acid (HAc) and formic acid (both from Merck) were used to improve stability of base-sensitive pesticides in the final extracts and as an acid modifier of the LC mobile phase, respectively. Acetone, dichloromethane, $\mathrm{n}$-hexane, petroleum ether (chromatography grade or similar quality) ethanol 95-96\%, anhydrous sodium sulphate (Riedel-de haen), sodium hydroxide, florisil 60-100 mesh (Merck), nitric acid $\left(\mathrm{HNO}_{3}\right)$ 
supra pure Merck -reagent grade, $2 \mathrm{~mol} / \mathrm{L} \mathrm{HNO}_{3}\left(130 \mathrm{ml}\right.$ of $\mathrm{HNO}_{3}$ is diluted to $1 \mathrm{Lwith}$ de-ionized water used for cleaning the digestion flasks, $0.3 \% \mathrm{HNO}_{3}$ ( $5 \mathrm{ml}$ conc. Acid is diluted to $1 \mathrm{~L}$ of $10 \mathrm{~g}$ of ammonium di-hydrogen phosphate $\left(\mathrm{NH}_{4} \mathrm{H}_{2} \mathrm{PO}_{4}\right)$ and $0.87 \mathrm{~g}$ of magnesium nitrate $\left\{\mathrm{Mg}\left(\mathrm{NO}_{3}\right)_{2} .6 \mathrm{H}_{2} \mathrm{O}\right\}, \mathrm{Pb}, \mathrm{Cd}, \mathrm{Cr}$, $\mathrm{Cu}$ and $\mathrm{Hg}$ stock standards, $1000 \mathrm{mg} / \mathrm{L}$ (Merck's ampoules). Intermediate and working solutions of elements were prepared from stock solution with different concentrations in $0.3 \mathrm{~N} \mathrm{HNO}_{3}$. Potassium nitrate for nitrate analysis, 99\% purity. Mobile Phase:: methanol/water/n-octyl ammonium phosphate which was prepared by mixing $800 \mathrm{ml}$ water, $200 \mathrm{ml}$ methanol and $1.63 \mathrm{ml} \mathrm{n}$-octyl amine, the $\mathrm{pH}$ of the solution was adjusted $\mathrm{pH}=4-6$ using $10 \%$ phosphoric acid solution (mobile phase should be freshly prepared every 3 days. Silica gel60(70-230) mesh ASTM Merck ) activated by heating $1 \mathrm{hr}$ at $150^{\circ} \mathrm{C}$ and then deactivated by adding $\mathrm{H}_{2} \mathrm{O} 1 \mathrm{ml} / 100 \mathrm{~g}$ anhydrous sodium sulphate (Riedel-deHaen).

Pesticide reference standard:

All reference pesticides (325 pesticides) were certified standards and were provided by Dr. Ehrenstorfer Gmbl. Gogginer st. 78 D-8900 Aughburg. Germany, The standard solution which used in nitrate analysis was potassium nitrate a ACROS $99 \%$ while copper, Chromium , lead, cadmium and mercury were from Merck

\section{Extraction Procedure:}

(1)Multi residue method:

a) Quick, Easy, Cheap, Effective, Rugged and Safe (QuEChERS) 2006 method of analysis European Committee for standardization

The extraction procedure was carried out according Sterven (2007), Anastassiades et al (2003) Ten gram of sample were weighed in $50 \mathrm{ml}$ PFTE tube, $10 \mathrm{ml}$ of acetonitrile was added and shacked vigorously for one minute, A buffer -salt -mixture were added and immediately shacked for one minute, the samples were centrifuged at 4000rcf for 5 minutes, and injected to LCMS/MS.

\section{b) Milk and Milk product method:}

Pesticide residues were extracted by Suzuki (1979) method which were adopted. Milk samples were extracted by centrifugation with $n$-hexaneacetonitrile-ethanol $(20: 5: 1 \mathrm{ml})$. The fat content was cleaned up on a florisil column and subjected to LC/MS/MS.

\section{C) Fish method}

Fish samples were extracted as described in PAM (1968). The petroleum ether extract was partitioned in petroleum ether acetonitrile and cleaned up using florisil column.

\section{D) Water method}

The AOAC 2003 was adopted for analysis of organochlorine and organophosphorous pesticide residues by extraction with dichloromethane.

\section{2) Heavy metals method:}

An analytical method described in thesis of Thabit (2002) was selected for determination of lead, cadmium copper where it is suitable for all kinds of food. As follows: Three-six grams of homogenized fresh samples were transferred to glass digestion flasks with $10 \mathrm{ml}$ of conc. $\mathrm{HNO}_{3}$. The 
solutions were boiled for 72 hours, depending on the sample matrix. The nitric acid solution was evaporated, and the residues was transferred with 0.3 $\mathrm{N} \mathrm{HNO}_{3}$ with $25 \mathrm{ml}$ volumetric flasks

\section{3) Aflatoxin analysis:}

Fifty grams of sample was extracted with $200 \mathrm{ml}$ methanolwater(80:20) solution and filtered AOAC(1995), $40 \mathrm{ml}$ of the filtrate was transferred to a $500 \mathrm{ml}$ reparatory funnel with $40 \mathrm{ml} 10 \% \mathrm{NaCl}$ solution and shacked gently for $1 \mathrm{~min}$. The lower queues layer was drained into another 500 separatory funnel, two $50 \mathrm{ml}$ of chloroform was added and shacked for $1 \mathrm{~min}$. The two lower layer were passed through $15 \mathrm{~g}$ of $\mathrm{NaSO}_{4}$, evaporated till dryness, followed by drivatisation using trifluro acetic acid

\section{4) Nitrates method of analysis:}

The method described by Cheng and Sang (1998) has been followed. Ten grams of the homogenized sample was extracted by $100 \mathrm{ml}$ of water and heated on water bath at $70^{\circ} \mathrm{C}$ for half an hour and shacked every five minuets, cooled at room temperature and filtered using whatman filter paper no.1, an aliquot from clear solution was taken for further purification by a syringe filter $(0.45 \mu \mathrm{m})$. The filtered solution was directly injected into the LC system HP 1100 series.

\section{Determination:}

\section{1) LC-MS/MS determination:}

Separation was performed on C18 column ZORBAX Eclipse XDBC18 $4.6 \times 150 \mathrm{~mm}, 5 \mu \mathrm{m}$ particle size. The injection volume was $5 \mu \mathrm{l}$. A gradient elution program at $0.3 \mathrm{ml} / \mathrm{min}$ flow, in which one reservoir contained $10 \mathrm{~m}$ mole ammonium formate and the other contained methanol. The ESI source was used in the positive mode, and nitrogen nebulizer, curtain, and other gas setting were optimized according to recommendations made by the manufacturer; source temperature was $300^{\circ} \mathrm{C}$, ion spray potential, $5500 \mathrm{v}$, decluster potential and collision energy were optimizes using a Harvard apparatus syringe pump by introducing individual pesticide solutions into the MS instrument to allow optimization of the MS/MS conditions. The Multiple Reaction Monitoring mode (MRM) was used in which one MRM was used for quantification and the other for confirmation.

\section{2) Heavy metals analysis:}

Atomic absorption spectrometer (AAS) \{Analytical technology, INC. Unicam 929\} equippedwith Graphite furnace with auto sampler and flame atomic absorption.

Typical furnace parameters for lead and cadmium in AAS are given in the following table (2) and table (3).

Table (2): Furnace parameters for AAS

\begin{tabular}{|l|c|c|c|c|}
\hline Step & Temp. $\left({ }^{\circ} \mathbf{C}\right)$ & Time (sec.) & Ramp $\left({ }^{\circ} \mathbf{C} / \mathbf{s e c}\right)$ & Gas flow (ml/min) \\
\hline Drying & 120 & 40 & $30(\mathrm{Cd}), 10(\mathrm{~Pb})$ & 2 \\
\hline Ashing & 800 & 20 & 50 & 2 \\
\hline Atomization & 1800 & 3 & 0 & 0 \\
\hline Cleaning & 2500 & 3 & 0 & 2 \\
\hline Cooling & 20 & 5 & 0 & 2 \\
\hline
\end{tabular}


Table (3): Instrumental Parameters of Atomic Absorption Spectrometer

\begin{tabular}{|c|c|c|c|c|c|}
\hline Parameter & $\mathbf{P b}$ & Cd & $\mathrm{Cu}$ & $\mathrm{Cr}$ & $\mathbf{F e}$ \\
\hline Technique. & Graphite & Graphite & Flame & Flame & Flame \\
\hline Wave length (nm) & 217.0 & 228.8 & 324.8 & & 246.3 \\
\hline $\begin{array}{l}\text { Slit band pass } \\
(\mathrm{nm})\end{array}$ & 0.5 & 0.5 & 0.5 & 0.5 & Full 0.2 \\
\hline Lamp current $\%$ & $75 \%-100 \%$ & $75 \%-100 \%$ & $75 \%-80 \%$ & $75 \%-100 \%$ & $75 \%-100 \%$ \\
\hline Signal type. & Transient & Transient & Continues & & Continues \\
\hline $\begin{array}{|ll|}\text { Back } \\
\text { correction }\end{array}$ & On & On & On & On & On \\
\hline Inert gas. & Argon & Argon & - & - & - \\
\hline Heating source. & $\begin{array}{l}\text { Electro } \\
\text { thermal }\end{array}$ & $\begin{array}{l}\text { Electro } \\
\text { thermal }\end{array}$ & $\begin{array}{c}\text { Air - } \\
\text { acetylene } \\
\text { with flow rate } \\
(1: 1 \mathrm{l} / \mathrm{min} .)\end{array}$ & $\begin{array}{c}\text { Air - } \\
\text { acetylene } \\
\text { with flow } \\
\text { rate }(1: 1 \\
\text { I/min }\end{array}$ & $\begin{array}{l}\text { Air - } \\
\text { cetylene with } \\
\text { flow rate }(1: 1 \\
\text { l/min.) }\end{array}$ \\
\hline
\end{tabular}

\section{3) Aflatoxin:}

\section{HPLC determination:}

HPLC was used for determination of aflatoxin. The injection volume $(25 \mu \mathrm{l})$ was applied into the reverse phase column and mobile phase \{water: methanol: acetonitrile $(60: 25: 15)\}$ was used with a flow rate of $1 \mathrm{ml} / \mathrm{min}$. The fluorescence detector was used with excitation $(360 \mathrm{~nm})$, emission $440 \mathrm{~nm}$ ), and the gain was at maximum.

4) Nitrate:

- Mobil phase: methanol/ water/n-octyl ammonium phosphate,

- HPLC column: MOS hypersil 5 × 200 x $4.6 \mathrm{~mm}$.,

- Injection volume: $10 \mu \mathrm{l}$,

- UV wave length $220 \mathrm{~nm}$,

- External standard method was used for calculation.

\section{RESULTS AND DISCUSSION:}

\section{a) Pesticide Residues:}

Data in table 4 and table 5 shows that: No contamination was found in the diet with organochlorine compounds and this may be attributed to the complete banding use of these compounds from a very long time ago, no contamination with PCB's was found in the diet (which checked by GC-ECD) because we do not have such sources of contamination found in our environment and it is consistent with our national monitoring programs Dogheim et al.,( 2002).

There is only a contamination with a few organophosphorous compounds in a very low levels. Profenofos, Azoxystrubin, Chlorfenapyr and L-cyhalothrin were found in low concentrations in cereals, veaetable, and fruits samples which were agreed with Egyption total diet studies Salama et al. (2003 a, b) 
J. Agric. Sci. Mansoura Univ., 34 (6), June, 2009

Table (4): Estimated Daily Intakes of pesticide residues.

\begin{tabular}{|c|c|c|c|c|c|}
\hline & Item & Pesticide & $\begin{array}{l}\text { Mean } \\
\text { conc. } \\
\mathrm{mg} / \mathrm{kg}\end{array}$ & $\begin{array}{c}\text { Food } \\
\text { consumed } \\
\text { by day in } \\
\text { grams } \\
\end{array}$ & $\begin{array}{c}\text { EDI } \\
\mathrm{mg} / \mathrm{kg}-\mathrm{B} . W .\end{array}$ \\
\hline Cereals & $\begin{array}{l}\text { Lentil a } \\
\text { Lentil b }\end{array}$ & $\begin{array}{l}\text { N.D } \\
\text { N.D } \\
\end{array}$ & & 3.3 & $\begin{array}{ll}-- \\
\end{array}$ \\
\hline Vegetables & $\begin{array}{l}\text { Veg. Mix. } \\
\text { Veg. Salad } \\
\text { Potato } \\
\text { a)Boiled } \\
\text { b)Cheeps } \\
\end{array}$ & $\begin{array}{c}\text { Profenofos } \\
\text { Profenofos } \\
\text { N.D } \\
\text { N.D } \\
\end{array}$ & $\begin{array}{c}0.01 \\
<L O Q\end{array}$ & $\begin{array}{r}384.9 \\
45.8\end{array}$ & 0.0000006 \\
\hline Pulses & $\begin{array}{l}\text { Cawpea D.beans } \\
\text { Medames }\end{array}$ & $\begin{array}{l}\text { N.D } \\
\text { N.D }\end{array}$ & & $\begin{array}{r}3.3 \\
18.9 \\
\end{array}$ & $\begin{array}{ll}-- \\
\end{array}$ \\
\hline & Macaroni & N.D & & & --- \\
\hline & $\begin{array}{l}\text { Rice } \\
\text { a)boiled } \\
\text { b) Fried } \\
\end{array}$ & $\begin{array}{l}\text { N.D } \\
\text { N.D }\end{array}$ & & 134.5 & --- \\
\hline & \begin{tabular}{|l|} 
Wheat \\
Belila \\
Bread \\
Bakery Products \\
\end{tabular} & N.D & & 348.8 & --- \\
\hline \multirow[t]{6}{*}{$\begin{array}{l}\text { Milk and milk } \\
\text { products }\end{array}$} & $\begin{array}{l}\text { Cheese a)skimmed } \\
\text { b)Full cream }\end{array}$ & N.D & & & --- \\
\hline & Milk & N.D & & 118.9 & --- \\
\hline & Chicken & N.D & & 27.7 & --- \\
\hline & Veal meat & N.D & & 9.9 & --- \\
\hline & Liver meat & N.D & & & --- \\
\hline & Fish & N.D & & 34.3 & --- \\
\hline \multirow[t]{3}{*}{ Fruits } & Apple & N.D & & 19.7 & \\
\hline & Grape & \begin{tabular}{|c|} 
Azoxystrubin \\
Sulfur
\end{tabular} & $\begin{array}{l}0.01 \\
0.23\end{array}$ & 42.7 & $\begin{array}{l}0.000007 \\
0.000163\end{array}$ \\
\hline & Orange & \begin{tabular}{|l|} 
Chlorpyrifos \\
L-cyhalothrn \\
Chlorfenpyr \\
\end{tabular} & $\begin{array}{l}0.03 \\
0.01 \\
0.01\end{array}$ & 40.5 & $\begin{array}{l}0.0000202 \\
0.0000067 \\
0.0000067\end{array}$ \\
\hline Nuts & Peanut & N.D & N.D & 1.1 & --- \\
\hline
\end{tabular}

N.D = Not Detected

Table (5): Estimated Daily Intakes of pesticides residues and its percentage to Acceptable Daily Intake ADI

\begin{tabular}{|l|l|l|l|l|}
\hline \multicolumn{1}{|c|}{ Pesticide } & Source & \multicolumn{1}{|c|}{ EDI } & $\begin{array}{c}\text { ADI } \\
\mathbf{M g} / \mathbf{K g} / \text { Peson/Day }\end{array}$ & \multicolumn{1}{|c|}{ EDI/ADIx100 } \\
\hline Azoxystrubin & Grape & 0.000007 & 0.1 (EU) & 0.007 \\
\hline Chlorfenapyr & Orange & 0.0000067 & $0.015(\mathrm{EU})$ & 0.00446 \\
\hline Chlorpyrifos & Orange & 0.0000067 & 0.1 (CAC) & 0.0000067 \\
\hline L-Cyhalothrin & Orange & 0.0000067 & 0.02 (CAC) & 0.00335 \\
\hline Profenofos & Veg. Mix. & 0.0000006 & 0.03 (CAC) & 0.0000018 \\
\hline
\end{tabular}


Salama, E. Y. et al.

b) Heavy Metals:

The contamination of the total diet as general is low and no exceeding for the contaminants to their corresponding established (PMADI or PTWI). Data in table 6 and table 7 shows that most of the contamination comes from cereals and vegetables.

Table (6): Estimated Daily Intakes of Heavy Metals.

\begin{tabular}{|c|c|c|c|c|c|c|c|}
\hline $\begin{array}{c}\text { Samples } \\
\text { from }\end{array}$ & Item & $\begin{array}{c}\mathrm{Fe} \\
\mathrm{mg} / \mathrm{kg}\end{array}$ & $\begin{array}{c}\mathrm{Cr} \\
\mu \mathrm{g} / \mathrm{kg}\end{array}$ & $\begin{array}{c}\mathrm{Zn} \\
\mathrm{mg} / \mathrm{kg}\end{array}$ & $\begin{array}{c}\mathrm{Cu} \\
\mathrm{mg} / \mathrm{kg}\end{array}$ & $\begin{array}{c}\mathrm{Cd} \\
\mu \mathrm{g} / \mathrm{kg}\end{array}$ & $\begin{array}{c}P d \\
\mu \mathrm{g} / \mathrm{kg}\end{array}$ \\
\hline Cereals & $\begin{array}{l}\text { Lentil a } \\
\text { Lentil b }\end{array}$ & 3.4 & $<L O Q$ & 1.62 & 4.7 & ND & ND \\
\hline Vegetables & $\begin{array}{l}\text { Veg. Mix. } \\
\text { Veg. Salad } \\
\text { Potato } \\
\text { a)Boiled } \\
\text { b)Cheeps } \\
\end{array}$ & 0.65 & ND & 0.26 & 0.84 & ND & 0.042 \\
\hline \multirow[t]{6}{*}{ Pulses } & Cawpea & 1.76 & ND & 1.17 & 1.8 & ND & 0.09 \\
\hline & D.beans & 2.34 & $<L O Q$ & 0.92 & 2.9 & ND & 0.09 \\
\hline & Medames & 0.93 & ND & 0.32 & 2.34 & ND & 0.08 \\
\hline & Macaroni & 1.04 & ND & 5.79 & 1 & $<L O Q$ & 0.402 \\
\hline & $\begin{array}{l}\text { Rice } \\
\text { a)boil } \\
\text { b) Fried }\end{array}$ & 0.62 & ND & 0.53 & 1.13 & ND & 0.132 \\
\hline & $\begin{array}{l}\text { Wheat } \\
\text { Belila } \\
\text { Bread } \\
\text { Bakery } \\
\text { Products } \\
\end{array}$ & 2.11 & ND & 0.21 & 1.44 & ND & 0.12 \\
\hline \multirow[t]{6}{*}{$\begin{array}{l}\text { Milk and milk } \\
\text { products }\end{array}$} & $\begin{array}{l}\text { Cheese } \\
\text { a)skimmed } \\
\text { b)Full } \\
\text { cream } \\
\end{array}$ & 0.44 & ND & ND & ND & 0.006 & ND \\
\hline & Milk & --- & --- & --- & --- & 0.009 & ND \\
\hline & Chicken & --- & --- & --- & -- & -- & -- \\
\hline & Veal meat & $\begin{array}{ll}-- \\
\end{array}$ & --- & --- & --- & --- & --- \\
\hline & Liver meat & & & & & & \\
\hline & Fish & --- & --- & --- & --- & $<\mathrm{LOQ}$ & 0.04 \\
\hline \multirow[t]{3}{*}{ Fruits } & Apple & & & & & & \\
\hline & Grape & & & & & & \\
\hline & Orange & ------ & ------ & ----- & ------ & ----- & ----- \\
\hline Nuts & Peanut & ---- & ------- & ------ & ------ & ----- & ---- \\
\hline \multirow{2}{*}{\multicolumn{2}{|c|}{$\begin{array}{c}\text { Total Estimated Dietary } \\
\text { Intake }\end{array}$}} & $\mathrm{Fe}$ & $\mathrm{Cr}$ & $\mathrm{Zn}$ & $\mathrm{Cu}$ & $\mathrm{Cd}$ & $\mathrm{Pb}$ \\
\hline & & $\begin{array}{l}7.386 \\
\mathrm{Mg} / \mathrm{Kg} \\
\text { /Day }\end{array}$ & $\begin{array}{l}0.1 \\
\mathrm{Mg} / \mathrm{Kg} \\
/ \mathrm{Day}\end{array}$ & $\begin{array}{l}0.262 \\
\mathrm{Mg} / \mathrm{Kg} \\
/ \text { week }\end{array}$ & $\begin{array}{l}0.017 \\
\mathrm{Mg} / \mathrm{Kg} \\
\mathrm{w} / \mathrm{day}\end{array}$ & $\begin{array}{c}0.083 \\
\mu \mathrm{g} / \mathrm{kg} \\
\mathrm{bw} / \mathrm{week}\end{array}$ & $\begin{array}{c}8 \\
\mu \mathrm{g} / \mathrm{kg} \\
\mathrm{bw} / \mathrm{week}\end{array}$ \\
\hline
\end{tabular}

Estimated Dietary Intake $=\sum$ Mean .Conc. ${ }^{*}$ Consumption

Dietary EXPOSUR $=\underline{\text { Estimated Dietary Intake }}{ }^{*} 100$

ADI 
J. Agric. Sci. Mansoura Univ., 34 (6), June, 2009

Table (7): Summary of estimated dietary exposures.

\begin{tabular}{|l|l|l|l|l|}
\hline \multicolumn{1}{|c|}{ Element } & $\begin{array}{c}\text { International } \\
\text { standard }\end{array}$ & \multicolumn{1}{c|}{ Type } & \multicolumn{1}{c|}{ Unit } & $\begin{array}{c}\text { Estimated } \mathbf{x 1 0 0} \\
\text { Accepted }\end{array}$ \\
\hline Iron & $8^{\mathrm{a}}$ & $\mathrm{RDI}^{*}$ & $\mathrm{mg} / \mathrm{day}$ & $92.2 \%$ \\
\hline Chromium & $1000^{\mathrm{b}}$ & $\mathrm{UL}^{* *}$ & $\mu \mathrm{g} / \mathrm{day}$ & $0.0001 \%$ \\
\hline Zinc & $1^{\mathrm{c}}$ & $\mathrm{PMTDI}$ & $\mathrm{mg} / \mathrm{kg} / \mathrm{bw} / \mathrm{week}$ & $3.1 \%$ \\
\hline Copper & $0.5^{\mathrm{d}}$ & $\mathrm{PMTDI}$ & $\mathrm{mg} / \mathrm{kgbw} / \mathrm{day}$ & $3.4 \%$ \\
\hline Cadmium & $7^{\mathrm{e}}$ & $\mathrm{PTWI}$ & $\mu \mathrm{g} / \mathrm{kgbw} / \mathrm{week}$ & $1.19 \%$ \\
\hline Lead & $25^{\mathrm{f}}$ & $\mathrm{PTWI}$ & $\mu \mathrm{g} / \mathrm{kgbw} / \mathrm{week}$ & $33.6 \%$ \\
\hline
\end{tabular}

a draft Australian and New Zealand Nutrient Reference Values

* RDI= Recommended Daily Intake

** UL $=$ Upper Limit

b SCF, 2003

c JECFA 1982

d JECFA 1982

e WHO,2004

f WHO,2000

Copper contaminated most of the items probably from using a fungicides or fertilizers, copper may be present in food in the shape of copper ions or copper salts, as a contaminants due to migration from food contact materials as water copper pipes. Lead is not easily extracted from the soil by plants and its occurrence in plants is often due to air pollution vehicles in roads beside farms, the occurrence of lead in food and drinks today is mainly due to many wears of use of lead technology and in particular to the use of alkyllead compounds as petrol additives. Most of the chromium, (Cr) present in food is in the form of trivalent chromium ( $\mathrm{Cr}$ III), No contamination of chromium and cadmium were not found in studied food item. The percentage of Estimated Dietary Intakes to its Provisional Maximum Tolerable Dietary Intakes (PMTDI) of $\mathrm{Zn}$ was $3.1 \%$. The results were in accordance with the information provided by different countries (Canada Denmark, Finland, Netherlands and USA) where the cereals and their products followed by vegetables as the largest contributors to such intake (Galal H. G. 1993).

\section{c) Aflatoxin:}

The mean concentration of the total $\mathrm{B} 1, \mathrm{~B} 2, \mathrm{G} 1$ and $\mathrm{G} 2$ were 3.6 $\mu \mathrm{g} / \mathrm{kg}$ and the Estimated Dietary Intakes which does not exceed $1 \mathrm{ng} / \mathrm{kg}$ b.w. /day JECFA (1997, 2001). Although, the JECFA have concluded that this limit or even less, still contribute to a liver cancer risk. Most of the results have only B1 and very small amount B2 and neither G1 nor G2 were found in any of the detected samples of nuts.

\section{d) Nitrates:}

Most of the samples were contaminated with nitrates but no exceeding for ADI recommended by JECFA $19953.65 \mathrm{mg} / \mathrm{kg}$ body weight. The percentage of EDI/ADI $=32.1 \%($ Table 8$)$. 
Salama, E. Y. et al.

Table ( 8): Estimated Daily Intakes of Nitrates.

\begin{tabular}{|c|c|c|c|c|c|}
\hline Sample from & Item & $\begin{array}{l}\text { Mean } \\
\text { conc. }\end{array}$ & $\begin{array}{l}\text { Food consumed } \\
\text { by day in grams }\end{array}$ & $\begin{array}{c}\text { EDI } \\
\mathrm{mg} / \mathrm{kg}- \\
\text { B.W. }\end{array}$ & $\begin{array}{c}\text { EDI } \\
\mathrm{mg} / \mathbf{k g}-\mathrm{B} . W .\end{array}$ \\
\hline Cereals & $\begin{array}{l}\text { Lentil a } \\
\text { Lentil b }\end{array}$ & & 3.3 & 20 & 0.0011 \\
\hline \multirow[t]{2}{*}{ Vegetables } & Veg. Mix. & & 384.9 & 163 & 1.045645 \\
\hline & $\begin{array}{l}\text { Potato } \\
\text { a)Boiled } \\
\text { b)Cheeps }\end{array}$ & & 54.8 & 84 & 0.07672 \\
\hline \multirow[t]{5}{*}{ Pulses } & $\begin{array}{l}\text { Cawpea D.beans } \\
\text { Medames }\end{array}$ & & 3.3 & 85 & 0.004675 \\
\hline & & & 18.9 & 8.7 & 0.00000005 \\
\hline & Macaroni & & & & \\
\hline & $\begin{array}{l}\text { Rice } \\
\text { a)boil } \\
\text { b) Fried }\end{array}$ & & 134.5 & 5.4 & 0.012105 \\
\hline & $\begin{array}{l}\text { Wheat } \\
\text { Belila } \\
\text { Bread } \\
\text { Bakery Products }\end{array}$ & & 348.8 & 3.7 & 0.022 \\
\hline \multirow[t]{6}{*}{$\begin{array}{l}\text { Milk and } \\
\text { products }\end{array}$} & $\begin{array}{l}\text { Cheese } \\
\text { a)skimmed } \\
\text { b) Full } \\
\text { cream }\end{array}$ & & & $\mathrm{Nd}$ & ----- \\
\hline & Milk & & 118.9 & 1.8 & 0.0035 \\
\hline & Chicken & & 27.7 & --- & --- \\
\hline & Veal meat & & 9.9 & $\mathrm{Nd}$ & ---- \\
\hline & Liver meat & & & & \\
\hline & Fish & & 34.3 & $\mathrm{Nd}$ & ------ \\
\hline \multirow[t]{3}{*}{ Fruits } & Apple & & 19.7 & 2.8 & 0.00009 \\
\hline & Grape & & 42.7 & 10 & 0.007 \\
\hline & Orange & & 40.5 & 2.0 & 0.00135 \\
\hline Nuts & Peanut & & 1.1 & 1.8 & 0.000033 \\
\hline \begin{tabular}{|c|} 
Total Estimated \\
Dietary Intake
\end{tabular} & & & & & $\begin{array}{c}1.174 \\
\text { MG/KG BW }\end{array}$ \\
\hline
\end{tabular}

REFERENCES

Anastassiades, M.; Lehotay, S. J..; Stainbahar, D. and Scheneek, F. J. J. (2003). Fast and Easy Multiresidue Method Employing Acetonitrile Extraction/Partitioning and "Dispersive Solid-Phase Extraction" for the Determination of Pesticide Residue in Produc. J. AOAC Int.,412-431.

AOAC (1995). Official Method of Analysis, Supplement March 991.31 (49.2.18), AOAC

AOAC (2003) Official Methods of Analysis, 991.07.

Cheng, C.F. and Sang, C.W. T.(1998).Simultaneous Determination of Nitrite, Nitrate and Ascorbic Acid in Canned Vegetables Juices by Reversephase Ion Interaction HPLC Food Additives and Contaminants 15(7):753-758.

Dogheim, S. M.; Gadalla, A. M.; El-Marsafy, (2001). Monitoring of Pesticide Residues in Egyptian Fruits and Vegetables in 1995. Journal of the Association of Official Analytical Chemists, 82,984-955. 
Dogheim, S. M.; Gadalla, A. M.; Salama, E. Y. El-Marsafy, (2002). Monitoring of pesticide residues in Egyptian fruits and vegetables in 1999. Food Addatives and Contaminants 19, 11 1015-1027.

EURACHEM /CITAC Guide CG 4 (2003) Quantifying Uncertainty in Analytical Measurement. English Edition 2000,ISBN 0948926155.

Food Balance Sheet (2006). Arab Republic of Egypt ,Ministry of Agriculture and Land Reclamation, Economic Affairs Sector(EAS) for the year 2004

Galal, H. G. (1993). Dietary intake levels in food and estimated intake of lead, cadmium and mercury. Food Additives and Contaminants 10(1): 115128.

Report of a joint USFDA/WHO. (2002.) International Workshop on Total Diet Studies in cooperation with the Pan American Health Organization. GEMS/Food Total Diet Studies .

JECFA(1982).Joint Expert Committee FAO/OMS Food Additives and Contaminants, Evaluation Technical Report series no. 683,WHO.

JECFA (1995). The Joint Expert Committee on Food Additives.

JECFA (1999).Evaluation of Certain Food Additives and Contaminants. 49 Report. WHO Technical Report Series no. 884, p69-77. Geneva.

QuEChERS (2006) Quick, Easy, Cheap, Effective, Rugged and Safe Method(QuEChERS) for the Determination of Pesticide Residues in Foods using LC-MS/MS, Standard, P.EN15662.

Report of the $2^{\text {nd }}$ International Workshop on Total Diet Studies Brisbane, Australia, 4-15 February 2002.

SCF (2003). Opinion of the Scientific Committee on Food on the Tolerable Upper Intake Level of Trivalent Chromium, European Commission.

Salama, E. Y.; Ayoub, M. M.; El-Sawi, M. A. and Khorshid, M. A. (2003a) A total Diet Study of Pesticides and Contaminants in Cairo and Giza governorates in 2001. The International Conference of Food Safety.

Salama , E. Y.; Khorshed, M. A.and Fahmy, S. M.( 2003b) Monitoring of Pesticides, Heavy Metals and Nitrates Residues in Some Ready-to-eat Baby Foods. Annals Agric. Sci., Ain Shams Univ., Cairo,48(2), 787-799

Sterven J. Lehotay (2007) Determination of Pesticide Residues in Food by Acetonitrile Extraction and Partitioning with Magnesium Sulfate Collaborative Study. Journal of AOAC vol. 90.2 485-492.

Suzuki, T. Ishikaw, Sato,N. and Sakal, K.(1979). Journal Association of Official Analytical Chemists 62,681-684.

Thabit W. M. (2002). Monitoring of Heavy Metals in Vegetables and Fruits, pp 18-27. M Sc. Thesis, Dept. of Agricultural Science. Institute of Environmental Studies and Research- Ain Shams University.

WHO (2000) Evaluation of Certain Food Additives and Contaminants (53 ${ }^{\text {rd }}$ Report of Joint FAO/WHO Expert Committee on Food Additives). WHO Technical Report series, No. 896. Geneva: World Health Organization.

WHO (2004). Evaluation of Certain Food Additives (61 ${ }^{\text {st }}$ Report of the Joint FAO/WHO Expert Committee on Food Additives). WHO Technical Report Series 922. Geneva: World Health Organization. 
Salama, E. Y. et al.

دراسة تعرض المستهلك المصري لمتبقيات المبيدات والملوثات في بعض الأبذاتئيه

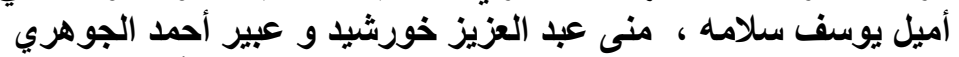

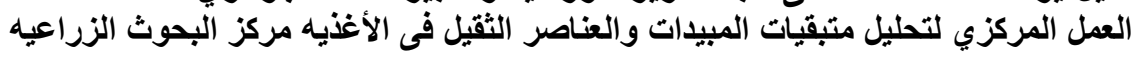

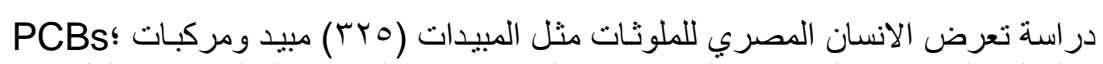

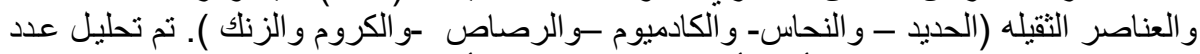

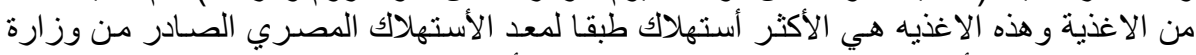

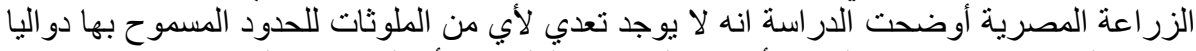

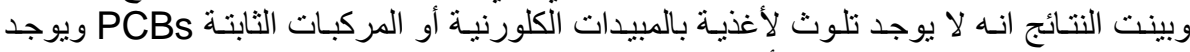

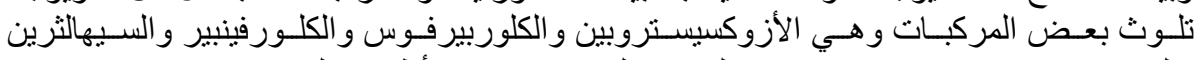

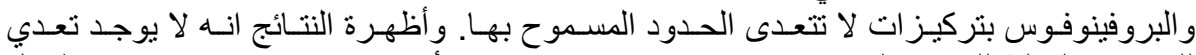

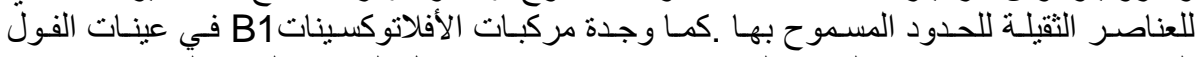

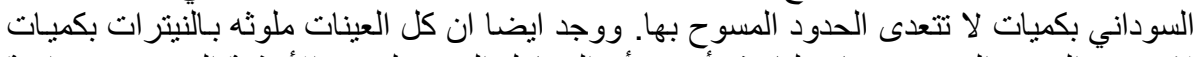

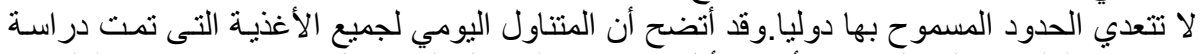

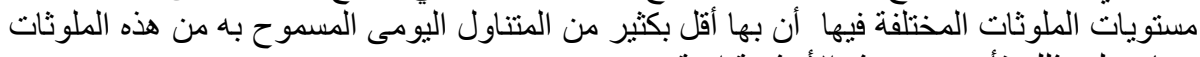
وبناء على ذلك فأن جميع هذه الأغذيهة امنة . 